\title{
A CALL FOR LAW SCHOOLS TO LINK THE CURRICULAR TRENDS OF LEGAL TECH AND MINDFULNESS
}

\author{
Katrina June Lee*
}

\section{INTRODUCTION}

MINDFULNESS practice has gone mainstream. Entertainment 1 celebrities, professional athletes, ${ }^{1}$ and Wall Street executives ${ }^{2}$ tout the benefits of mindfulness practice. Large corporations have used mindfulnessbased tools in their employee training. ${ }^{3} \mathrm{~A}$ broad range of groups, from journalists to philanthropists to the chaplaincy unit of the U.S. Army, has engaged in

* Associate Clinical Professor of Law, The Ohio State University Moritz College of Law. The author is grateful to Susan Azyndar, Shailini George, Daniel W. Linna, Jr., Ellie Margolis, Ingrid Mattson, Deborah Merritt, Kathleen Dillon Narko, and Gabriel H. Teninbaum for their review and comments. The author also thanks Joseph Holtgreive and Leonard Riskin for their contributions.

1. Celebrities like supermodel Gisele Bundchen and popstar Katy Perry reportedly practice meditation. Steal Her Mantra: Celebrities Who Meditate, Elle Australia (Apr. 8, 2015), http:// www.elle.com.au/elle-fit-club/mind-body/2015/4/steal-her-mantra-13-celebrities-who-meditate/ste al-her-mantra-celebrities-who-meditate-image-3/. Stephen Curry, the NBA's 2015 MVP, spends 1hour sessions floating in a sensory-deprivation pod of salt water and says the hour gives him a "nice boost of focus and perspective." Sam Alipour, Stephen Curry on Copying the Warriors' Way: 'You Won't Have the Personnel', ESPN (Dec. 8, 2015), http://www.espn.com/nba/story/_/id/ 14314860/stephen-curry-small-ball-mj-gunning-record-books ("For advanced practitioners, floating is a meditation-hack and an expressway to mindfulness, the state of being present and free of the mind's unwanted chatter."). The Chicago Bulls and L.A. Lakers professional basketball teams "use mindfulness to improve focus and work on the team aspect of the game." Shailini Jandial George, The Cure for the Distracted Mind: Why Law Schools Should Teach Mindfulness, 53 Duq. L. Rev. 215, 237-38 (2015). See also Jeena Cho \& Karen Gifford, The Anxious Lawyer: An 8-Week Guide to a Joyful and Satisliying Law Practice Through MindFulness AND MEditation 25-26 (2016) (stating "highly accomplished business people and professionals who are ... avowed meditators" include Marc Benioff, CEO of Salesforce.com; Evan Williams, Cofounder of Twitter; and Oprah Winfrey, Chairwoman and CEO of Harpo Productions, Inc.); Ashley Ross, How Meditation Went Mainstream, Time (Mar. 9, 2016), http://time.com/ 4246928/meditation-history-buddhism/.

2. Wall Street employers like Goldman Sachs Group offer meditation classes to their employees. Katherine Burton \& Anthony Effinger, To Make a Killing on Wall Street, Start Meditating, BLOOMBERG MARKeTs (May 28, 2014, 12:00 AM), http://www.bloomberg.com/news/ articles/2014-05-28/to-make-killing-on-wall-street-start-meditating.

3. Nathalie Martin, Think Like a (Mindful) Lawyer: Incorporating Mindfulness, Professional Identity, and Emotional Intelligence into the First Year Law Curriculum, 36 U. ARK. LiTTLE ROCK L. REv. 413, 417 (2014). 
mindfulness training. ${ }^{4}$ In 2014, mindfulness made the cover of Time Magazine. ${ }^{5}$ Silicon Valley tech culture in particular has featured prominently in the ascent of mindfulness in popular consciousness. ${ }^{6}$ For example, Google pioneered the "Search Inside Yourself" mindfulness program and has offered "mindful lunches" and labyrinths for walking meditations. ${ }^{7}$ A plethora of recent publications call for mindfulness to help achieve calm, joy, and productivity in a digital world. ${ }^{8}$

Meanwhile, law schools are evolving to embrace the world outside their walls, with mindfulness and legal technology trending in law school curricula, but largely separately. ${ }^{9}$ As a result, law students and law schools probably have not yet fully realized the benefits of education centered on legal technology and innovation. The mindfulness and legal tech trends in law schools represent laudable efforts by legal educators to better prepare aspiring lawyers for the realities of law practice. Law schools, however, can reap even richer benefits for their students by linking these trends and thereby reflecting a growing practice in the tech industry and other fields.

In this article, I propose that as law schools move in the direction of increased legal technology focus, they deliberately link legal technology education with mindfulness training. At this point in the history of legal education, law schools are at an unprecedented juncture to develop a legal technology curriculum with maximum potential for creativity, empathy, openness, and compassion. The lessons that legal technology educators seek to teach would be strengthened by mindfulness training. Much of legal tech education focuses on user-centered design and the application of tech tools, design principles, and creativity to increase access to justice. Mindfulness training, often referred to as "brain-hacking," can help manage bias, enhance creativity, and strengthen focus.

Part II of this article discusses the definitions of mindfulness and reports on the mindfulness curriculum trend in legal education. Part II further provides an

4. See George, supra note 1, at 237 (citing Leonard Riskin, The Contemplative Lawyer: On the Potential Contributions of Mindfulness Meditation to Law Students, Lawyers, and Their Clients, 7 Harv. Negot. L. Rev. 1, 4 n.6 (2002)); Daniel. Goleman, Focus: The Hidden Driver OF EXCELLENCE 200 (HarperCollins 2013) ("Mindfulness programs have been deployed by groups as diverse as the chaplaincy unit of the U.S. Army, Yale Law School, and General Mills, where more than three hundred executives are applying mindful leadership methods.").

5. See Time MAG. (Feb. 3, 2014), http://content.time.com/time/covers/0,16641,20140203,00 .html ("The Mindful Revolution" was featured on the front cover).

6. Noah Shachtman, In Silicon Valley Meditation Is No Fad. It Could Make Your Career, WIRED (June 18, 2013, 6:30 AM), http://www.wired.com/2013/06/meditation-mindfulness-siliconvalley/.

7. Id. See also Search Inside Yourself Leadership Inst., https://siyli.org/about/ (last visited Nov. 9, 2016).

8. In his 2016 book, Mindful Tech: How to Bring Balance to Our Digital Lives, Professor David Levy explores "how to live a rich and meaningful life while participating in both the Fast World and the Slow World-in the fast-paced, crazy-busy, information-intensive world ... and in the slower-paced, calmer world that we sometimes touch in moments of quiet contemplation." David M. Levy, Mindful. Tech: How to Bring Balance to Our Digital Lives, at ix (2016).

9. Martin, supra note 3, at 414. At least 20 ABA-accredited law schools offer meditation programs. Id. Across the country, from Berkeley Law School to the University of Miami Law School, mindfulness has a strong presence in the curriculum of many law schools. Id. 
overview of the benefits of mindfulness training in law school curricula. Part III discusses the types of and rise in legal technology offerings at law schools. Part III continues with a look at the reasons proffered for including legal tech education in law school curricula. Part IV explains why law schools should explicitly connect mindfulness training with opportunities for legal technology learning, and provides suggestions for how law schools might make that connection. Part V concludes.

Ultimately, this article proposes a holistic approach to the newest trends in legal education curriculum-mindfulness and legal technology - that will help produce a more balanced, more empathetic, and an even more qualified group of law school graduates.

\section{Mindfulness in Law School Curriculum}

The mindfulness field in legal education has enjoyed a considerable surge, both in scholarly writings and in the classroom. ${ }^{10}$ Writings on the topic have proliferated. Since 1999, at least 100 pieces have been published in "law reviews, bar journals, and national periodicals addressing the role of mindfulness in legal education and across the [legal] profession." 11 At least two dozen law review articles tout the benefits of yoga or meditation to those in the legal profession. ${ }^{12}$ An entire issue of the Journal of Legal Education focused on mindfulness in the legal field. ${ }^{13}$ Scholars have made powerful pleas for mindfulness to be included in the law school curriculum, and mindfulness training is increasingly happening in many law schools. ${ }^{14}$

But, what is mindfulness? This section defines mindfulness and discusses its growing presence in law schools. Finally, this section sets out many of the declared benefits of and reasons for mindfulness training for law students and lawyers. Those benefits can significantly enhance the goals of legal technology training in law schools.

10. See, e.g., Tim Iglesias, Offering and Teaching Mindfulness in Law Schools, 49 U.S.F. L. REv. F. 24, 24 (2015), http://lawblog.usfca.edu/lawreview/offering-and-teaching-mindfulness-inlaw-schools/. See Karmah Elmusa, Law Schools Teach the Practice of Meditation, CAl. Law. (June 2013), http://www.callawyer.com/clstory.cfm?eid=929087\&wteid=929087_Law_Schools_ Teach_the_Practice_of_Meditation (listing UC Berkeley, University of San Francisco, UCLA, University of Connecticut, Phoenix School of Law, University of Miami, University of Florida, and University of Missouri as schools that have embraced mindfulness programs). See also Martin, supra note 4 , at $414-15$.

11. Scott L. Rogers, The Role of Mindfulness in the Ongoing Evolution of Legal Education, 36 U. Ark. Litrle Rock L. Rev. 387, 388 (2014). Also, in 2016, the book The Anxious Lawyer: An 8Week Guide to a Joyful and Satisfying Law Practice Through Mindfulness and Meditation, coauthored by Jeena Cho and Karen Gifford, was released by ABA Publishing.

12. Martin, supra note 3, at 415. See, e.g., Debra S. Austin, Killing Them Softly: Neuroscience Reveals How Brain Cells Die from Law School Stress and How Neural Self-Hacking Can Optimize Cognitive Performance, 59 Loy. L. Rev. 791 (2013). In 2015, the Wall Street Journal covered the specific topic of a mindfulness trend in the legal profession. Jacob Gershman, Lawyers Go Zen, With Few Objections, WALL. Sr. J. (June 22, 2015, 12:55 AM ET), http://www.wsj.com/articles/ lawyers-go-zen-with-few-objections-1434586250 (the article begins, "Soft winds of change are rustling through the legal profession.").

13. Martin, supra note 3, at 415.

14. See, e.g., George, supra note 1, at 242-43. 


\section{A. Mindfulness Defined}

Mindfulness can be defined as present awareness. ${ }^{15}$ It has been described as "an experiential practice and a way of being more attuned and responsive to present moment concerns." 16 Mindfulness practice "involves intentionally paying attention to present moment experience in a way that is engaged and unassuming." 17 Mindfulness is "the practice of fully engaging and being in our life. Instead of escaping to the past, or the future, mindfulness asks us to take our seat-right here, right now. . . . When we're mindful, we're in the present moment. . . . When we practice mindfulness, we're accessing our inner calm."18

Mindfulness practice can take many forms. Mindfulness is usually introduced to law students and lawyers in the form of "sitting practice."19 Following are "sitting practice" instructions: 20

1. Assume a seated posture that is upright and stable.

2. Lower or close your eyes.

3. Bring your attention to an object (e.g., the movement of the breath through the body).

4. Form the intention to keep your attention on the object.

5. When you notice your mind wandering, bring your attention back to the object.

6. Do this for a few minutes. ${ }^{21}$

Mindfulness practice can also involve daily life activities such as eating, walking, and showering. ${ }^{22}$

15. Martin, supra note 3, at 416.

16. Rogers, supra note 11, at 389.

17. Id.

18. Сho \& GifFord, supra note 1 , at 63 .

19. Rogers, supra note 11 , at 393.

20. Id.

21. Id.

22. See, e.g., David Gelles, How to Meditate, N.Y. TIMEs, http://www.nytimes.com/well/ guides/how-to-meditate (last visited Oct. 31, 2016); Сно \& GIFFORD, supra note 1, at 58 (instructions for "mindful showering"); id. at 67 ("Even the most mundane activity can be done with mindfulness."). Many legal educators have also written about the benefits of journaling and reflection in law school classrooms. See, e.g., J.P. Ogilvy, The Use of Journals in Legal Education: A Tool for Reflection, 3 Cl.INICAL L. REv. 55 (1996). While mindfulness training and journal writing in law school can serve overlapping pedagogical goals, this article focuses on mindfulness training. Ogilvy argues that "the journal is a pedagogical tool worthy of more explicit attention by both clinical law teachers and non-clinical faculty alike." Id. at 56. Ogilvy writes, "[The] journal encourages writing; probing beneath the surface of problems; thinking more deeply about ... [the] process of learning; and taking more responsibility for [the student's] own learning. . . . Used in externships and clinics, the journal promotes reflective behavior by encouraging students to record critical incidents from their lawyering experiences for deeper examination and study." Id. at 60 . Ogilvy, acknowledging that any set of goals for the use of journals in law school would be to some degree idiosyncratic and tentative, set seven goals for the use of journals in his classroom that included fostering self-awareness and releasing stress. $I d$. at 63 . 


\section{B. A Growing Trend in Legal Education}

Mindfulness meditation has increasingly become a part of law school curricula. ${ }^{23}$ Initially, the law schools at Yale University, Columbia University, and the University of California at Berkeley offered "meditation retreats" for law students. ${ }^{24}$ At the University of Miami Law School, Professor Scott Rogers began directing the Mindfulness in Law Program. ${ }^{25}$ Many other law schools have joined the mindfulness trend. The University of Miami program was followed by the City University of New York's Contemplative Urban Lawyering Program, the University of California at Berkeley's Berkeley Initiative for Mindfulness and the Law, and the University of Florida's Initiative on Mindfulness in Law and Dispute Resolution. ${ }^{26}$ Law schools including the University of Missouri and Northwestern University offer courses with a mindfulness component. ${ }^{27}$

The types of law school courses that include a mindfulness component range from courses with mindfulness in the title to emotional intelligence, professional responsibility, and dispute resolution courses. ${ }^{28}$ At Berkeley Law School, first-year law students are encouraged to participate in an "Introduction to Mindfulness" non-credit course. ${ }^{29}$ Second-year and third-year Berkeley Law students are invited to take the 2-credit seminar "Effective and Sustainable Law Practices: The Meditative Perspective." 30 The University of New Mexico School of Law incorporated mindfulness and emotional intelligence in its professionalism class, called "Practicum." 31 The University of Buffalo Law School has offered the course "Mindfulness and Professional Identity: Becoming a Lawyer While Keeping Your Values Intact."32 University of Miami law professors Scott Rogers and Jan Jacobowitz created the course "Mindful Ethics." 33 In that course, "class discussion weaves mindfulness insights and

23. George, supra note 1 , at $242-43$.

24. Id. The Law Program of the Center for Contemplative Mind in Society, headquartered in Northampton, Massachusetts, for years sponsored "annual retreats and other gatherings for lawyers, judges, professors, and students. It held its first retreat in 1998, for Yale Law School students and faculty, led by mindfulness luminary Joseph Goldstein." Barry Boyce, The Law of Mindfulness, MinDFul (Aug. 26, 2010), http://www.mindful.org/the-law-of-mindfulness/. The Law Program ceased to exist as a free-standing program in 2012, but program materials are still archived at http:// www.contemplativemind.org/archives/law. See also Austin, supra note 13, at 851.

25. George, supra note 1, at 243.

26. $I d$.

27. Id. at 242; Wellness Curriculum, Nw. Univ. Pritzker Sch. Of Law, http://www.law.north western.edu/law-school-life/studentservices/wellness/curriculum/index.html (last visited Nov. 14, 2016).

28. George, supra note 1 , at 242.

29. Mindfulness at Berkeley Law, BerkelEY LAw, https://www.law.berkeley.edu/students/ mindfulness-at-berkeley-law (last visited Oct. 31, 2016).

30. $I d$.

31. Professor Martin describes the incorporation of mindfulness into her professionalism class at University of New Mexico Law School. Martin, supra note 4, at 416. Journaling became a "backbone" of the course. Id. at 431. Journaling included empathy journaling. Id. at 441 . Professor Martin noted, "[C]linical law professors have long recognized the benefits of student journals for promoting self-awareness and reflection, enhancing learning from experience, releasing stress, and developing lifelong self-directed learning habits." Id. at 431.

32. George, supra note 1, at 242.

33. Rogers, supra note 1.1, at 403. 
practices into the application of the professional responsibility rules in one's daily life, both personally and professionally." 34

Law school faculty have developed accessible ways to introduce students to mindfulness. ${ }^{35}$ In my negotiations course at The Ohio State University Moritz College of Law, I engage students in a 3-minute mindfulness meditation exercise as part of a course module on mindfulness and negotiations. Professor Todd Peterson of George Washington University Law School has started his civil procedure class with a two-minute mindfulness exercise. ${ }^{36}$ Professor Margaret deGuzman of Temple University Law School has led willing students in an optional eight-minute mindfulness practice before the scheduled start of her criminal law class and transitional justice seminar. ${ }^{37}$ At Berkeley School of Law, Professor Jonathan Simon has taken time in his criminal law class for a guided "mindful minute." 38 As these examples illustrate, integrating mindfulness into a course can involve just a few minutes of class time, or students can even be invited to join for an optional mindfulness exercise before the start of class.

\section{Benefits of Mindfulness Training}

Mindfulness training holds many benefits for lawyers and aspiring lawyers. ${ }^{39}$ These benefits can help serve many of the goals of a legal technology curriculum. In the past half-century, thousands of studies have been conducted on the effects of meditation and the changes "in the brain and body of the meditator." 40 The impact of mindfulness training on lawyers' well-being and performance is a subject of ongoing study. ${ }^{41}$ Mindfulness practice can help boost creativity, memory, emotional intelligence, relationships, empathy, regulation of emotions, attention span, focus, and overall health and happiness, while also reducing implicit bias. ${ }^{42}$ With mindfulness training, law students, who are distracted on a minute-by-minute basis by social media and their mobile devices, can develop much-needed focus and improved attention span. ${ }^{43}$ Mindfulness training can empower students to better handle complex situations that lawyers routinely face. ${ }^{44}$ Some benefits of mindfulness can begin to appear with as little

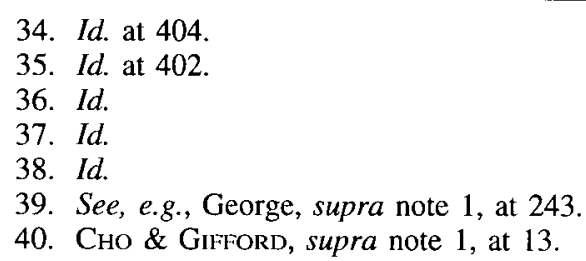

41. Dr. John Paul Minda of the Department of Psychology and The Brain and Mind Institute at the University of Western Ontario and lawyer-author Jeena Cho are investigating "the relationship between mindfulness meditation and performance and well-being in lawyers." The NAWL Book Club Presents: The Anxious Lawyer, ANxious Law., http://theanxiouslawyer.com/nawl-book-club/ (last visited Nov. 15, 2016). As part of Cho and Minda's research, the National Association of Women Lawyers and the Seyfarth Shaw LLP law firm hosted an 8-week course for lawyers on "bringing mindfulness and meditation into your legal practice as well as your daily life" that used the book The Anxious Lawyer by Jeena Cho \& Karen Gifford. Id.

42. Emma Seppala, How Meditation Benefits CEOs, Harv. Bus. Rev. (Dec. 14, 2015), https:// hbr.org/2015/12/how-meditation-benefits-ceo. See also George, supra note 1, at 216, 222.

43. George, supra note 1 , at 217-20.

44. Id. at 244. 
as twenty minutes of practice for just four days, and sustained practice for longer periods of time reaps higher benefits. ${ }^{45}$

In sum, mindfulness training can help develop law students into better lawyers, and any law school not offering mindfulness training misses out on maximizing the benefits of its education. Following is an overview of the benefits of mindfulness training for law students and lawyers.

\section{Attention, Memory, and Learning}

Law students faced with the pressures of a competitive environment often resort to multitasking as a path to success. Research, however, shows that multitasking is inefficient; specifically, multitasking may adversely affect the part of the brain needed for focused attention. ${ }^{46}$ Cognitive psychology and neuroscience studies show that "'human attention is a limited resource, and that multitasking requires rapid task switching" "and that rapid task switching negatively affects speed and accuracy. ${ }^{47}$ Enter mindfulness meditation. The areas of the brain affected by multitasking can be strengthened with mindfulness meditation. ${ }^{48}$ As Northwestern University Professor Leonard Riskin elegantly wrote, mindfulness meditation helps "reclaim focus and exercises the muscle of attention, which helps us to become more expert at paying attention." 49 Mindfulness helps increase a person's ability to pay attention to attention, to "notice that you are not noticing what you should" and then to correct one's focus. ${ }^{50}$ Mindfulness practice has been compared to "lifting weights" because it "can strengthen attention" just like "doing reps" "build[s] up your biceps."

45. Goleman, supra note 4, at 203 (citing Fadel Zeidan et al., Mindfulness Meditation Improves Cognition: Evidence of Brief Mental Training, 19 ConsCiousness \& CoGNITion 597 (2010)).

46. George, supra note 1 , at 222-23.

47. Id. at 223 (quoting David M. Levy et al., The Effects of Mindfulness Meditation Training on Multitasking in a High-Stress Information Environment, 2012 GRAPHICS INTERFACE 45, https://faculty.washington.edu/wobbrock/pubs/gi-12.02.pdf; Maria Konnikova, The Power of Concentration, N.Y. TIMEs, Dec. 16, 2012, at SR8, http://www.nytimes.com/2012/12/16/opinion/ sunday/the-power-of-concentration.html?pagewanted=all).

48. Id.

49. Riskin, supra note 4, at 26.

50. Goleman, supra note 4, at 197.

51. George, supra note at 1 , at 221 (citing Marc Parry, You're Distracted. This Professor Can Help, Chron. Higher Educ. (Mar. 24, 2013), http://chronicle.com/article/Youre-Distracted-This/ 138079). See also Jan L. Jacobowitz, The Benefits of Mindfulness for Litigators, 39 LiTIG. 27, 28 (2013) ("Doing so creates a laboratory from within which you notice your mind's tendency to wander. So, when you realize that your mind is wandering, just take note of its wandering, noticing the thought that is distracting you; then decide to let the thought go for the moment and return to a focus on the breath. Some people benefit from joining a contemplative group that sits together in silence or in a guided meditation. Others ... close their office doors and listen to a recorded guided meditation. Still others prefer solitude and complete quiet."); Gol_EMAN, supra note 4, at 169 ("More-experienced meditators, one study found, were able to deactivate their medial strip more rapidly after noticing mind wandering .... There was more neural connectivity between the region for mind wandering and those that disengage attention. The increased connectivity in the brains of the long-term meditators, this study suggests, are analogous to those competitive weight lifters with the perfect pecs.") (internal citation omitted). 
Because legal work requires focused attention, mindfulness can be critical to helping a lawyer achieve maximum effectiveness.

Improving working-memory capacity improves learning. ${ }^{52}$ Mindfulness training can help increase working-memory capacity when it strengthens the area of the brain responsible for higher cognitive functioning. ${ }^{53}$ Questions designed to prompt a person to reflect on her level of mindfulness include questions about remembering what was just said in a conversation and remembering the person's morning commute. ${ }^{54}$ The less a person remembers, the greater the likelihood that the person "zones out" rather than tunes in and focuses on her experience in the present. ${ }^{55}$ In addition, working-memory capacity can be enhanced with intensive meditation practice. ${ }^{56}$ In one study, researchers compared a group of inexperienced meditators who underwent "intensive" mindfulness meditation training for ten days with a group that did not have any such training. ${ }^{57}$ The group that received the training experienced a rise in working-memory capacity and a "statistically significant improved capacity for sustained attention during tasks." 58

\section{Happiness and Stress Relief}

Mindfulness practices are well known for improving peace of mind by relieving stress. Decreasing stress can lead to healthy biological changes as well. In his landmark book, Full Catastrophe Living, Jon Kabat-Zinn describes the eight-week Mindfulness-Based Stress Reduction ("MBSR") program that he developed at the University of Massachusetts Medical Center and with which millions of people have engaged. ${ }^{59}$ Through the MSBR program, individuals found relief through meditation and yoga. ${ }^{60}$ As Kabat-Zinn explains, bringing mindfulness to any activity can transform that activity into a form of meditation. ${ }^{61}$ Kabat-Zinn once noted the impact of mindfulness on healthy behaviors, stating, "Our patients typically come in because they're overwhelmed by stress or pain. But there's something about paying attention to your own inner states ... . People on their own stop smoking or change the way they eat . . , though as a rule we never say anything directly about these."62 By improving state of mind, clarity of thinking, and efficiency, mindfulness can help lawyers experience less stress, more happiness, and career satisfaction.

52. George, supra note at 1 , at 225 .

53. Id. at 226.

54. Goleman, supra note 4, at 201.

55. Id. at 202.

56. George, supra note 1 , at 228.

57. Id.

58. Id.

59. Jon Kabat-Zinn, Full Catastrophe Living: Using the Wisdom of Your Body and Mind to Face Stress, Pain, and Illness (rev. ed. 2013). See also Cho \& GifFord, supra note 1, at 39-40 (discussing Kabat-Zinn's MBSR program).

60. КАвАт-ZinN, supra note 59, at 197-99.

61. Id. at 9 .

62. Goleman, supra note 4 , at 198. 
By reducing stress, mindfulness practice can lead to greater happiness. ${ }^{63}$ Assume that each person has a base or "default" level of happiness. ${ }^{64}$ When stress is reduced, meditation can help increase that level of base happiness. ${ }^{65}$ The significance of these happiness benefits cannot be underestimated. As Professor Debra Austin wrote, "The stresses of attending law school are legendary." 66 One survey of $1 \mathrm{~L}$ law students about their "dominant feeling(s)" at the end of the school year resulted in answers "disproportionately focused on anxiety and stress." 67 Research has shown that "law students are less happy after they finish law school than before they started." 68 Attorneys themselves are known to be an unhappy group. ${ }^{69}$ Lawyers in general are more likely to be depressed compared to the general population. ${ }^{70}$ Mindfulness practice therefore can help address a major issue among law students and lawyers by decreasing stress and raising their default level of happiness.

\section{Empathy, Compassion, and Emotional Intelligence}

Mindfulness practices can improve emotional intelligence and interpersonal interactions and can help law students develop compassion and empathy. ${ }^{71}$ Mindfulness improves emotional self-regulation; it helps to widen "the gap between impulse and action, in part by building meta-awareness, the capacity to observe our mental processes rather than just be swept away by them."72 This self-regulation produces a decision point that allows a person to "squelch troublesome impulses" and can lead to improved interpersonal interactions. ${ }^{73}$

63. Martin, supra note 3, at 424.

64. Сно \& GifFord, supra note 1, at 113-14 ("Western psychology suggests that each person has a 'set point' or default level of happiness. While life events like falling in love or experiencing a life crisis may temporarily make us uncharacteristically joyful or melancholy, according to this view, eventually we will return to our emotional set point.").

65. Id.

66. Austin, supra note 12 , at 794.

67. Id.

68. Martin, supra note 3 , at 423 .

69. Id. at 424 .

70. Id. (explaining that lawyer depression is prevalent). See also Hugh Grady, Study Shows Lawyers Have Higher Rates of Problem Drinking and Mental Health Issues, Iowa Law., May 2016, at 5, http://www.americanbar.org/content/dam/aba/administrative/lawyer_assistance/ls_colap _may_2016_iowa_lawyer_magazine.authcheckdam.pdf ("The newest study of lawyers in 25 years demonstrates that the profession has a higher rate of substance abuse and mental health issues than other professions and the general population."). In 2015, the American Bar Association Commission on Lawyer Assistance Programs and the Hazelden Betty Ford Foundation completed a study of lawyers. Id. The study's results were published in the February issue of the Journal of Addiction Medicine. Id. Approximately 11,000 lawyers completed the Depression Anxiety Stress Scales (DASS-21). Id. Nearly $61 \%$ of the surveyed lawyers reported concerns with anxiety, and $42 \%$ reported concerns with depression at some point in their career. Id. See also, e.g., CHo \& Gifford, supra note 1, at 1; Steven Keeva, Transforming Practices: Finding Joy and Satisfaction in the Legal Life 5 (1999) (discussing Johns Hopkins University study that looked at incidence of depression among members of 105 different occupations; lawyers were at the top of the list).

71. Goleman, supra note 4, at 198.

72. Id. at 199.

73. Id. 
Mindfulness practices can also help build empathy. Students entering law school are not a particularly empathetic group. ${ }^{74} \mathrm{Law}$ students given the MyersBriggs assessment generally turn out to be "Thinkers, not Feelers." 75 Law school may even negatively impact students' ability to empathize. Many have cited lack of empathy as indicative of a problem with the current state of legal education. ${ }^{76}$ One professor noted that her students seemed to arrive in law school with empathy intact, but she observed that empathy gradually eroded over time in law school. ${ }^{77}$

Mindfulness can help with regulating emotions and with responding with empathy. ${ }^{78}$ In two studies involving medical students and graduate psychology students, "those who received eight or ten weeks of mindfulness training experienced increased levels of self-reported empathy." 79 At a biotech firm where employees participated in the "Search Inside Yourself" program, according to Stanford psychologist Philippe Goldin, program participants showed an increase in "empathic concern" for others and in the ability to listen better. ${ }^{80}$

Mindfulness training also increases both compassion and self-compassion. Compassion has been defined as having four parts: " 1 . Recognizing difficulties or suffering ... [,] 2. Noticing our innate desire to help those who are experiencing difficulties[,] 3. Recognizing that difficulties, suffering, and pain are part of the human condition[, and] 4. Taking some step to alleviate or help." 81 The most skillful attorneys bring compassion to their law practice. ${ }^{82}$ Compassion can give a lawyer a "fuller understanding of each side" in a client's matter, allowing the lawyer to be in a "better position to more skillfully think" through a case. ${ }^{83}$ Lawyers who can engage compassionately with the plights and psychology of their clients may come up with more creative solutions. ${ }^{84}$ Compassionate lawyering can help move lawyers away from seeing every client's problem as a zero-sum game and towards solutions that address the client's true core concerns and needs. ${ }^{85}$

Historically, law schools have fallen short in teaching about the role of emotions in human conduct. "What we fail to teach, and what we fail to learn in law school, is humanity," laments lawyer-authors Jeena Cho and Karen Gifford. ${ }^{86}$ That gap in training could be addressed through mindfulness training.

74. Douglas O. Linder \& Nancy Levit, The Good Lawyer: Seeking Quality in the Practice of Law 19 (2014).

75. Id.

76. George, supra note 1 , at 235 .

77. Martin, supra note 3, at 425.

78. Id.

79. George, supra note 1 , at 235.

80. See Goleman, supra note 4, at 201. See also Search Inside Yourself Leadership Inst., supra note 7.

81. CHO \& GIFoRD, supra note 1 , at 112.

82. See id. at 127.

83. Id. at 126.

84. Id.

85. Id. See generally Robert Fisher \& William Ury, Getring to Yes (Penguin Books 3d ed. 2011) (on negotiating for mutual gain rather than approaching each negotiation as a zero-sum game).

86. See Cho \& Gifford, supra note 1 , at 125. 
Research shows that compassion can be increased after a short period of mindfulness practice. In one study examining the impact of mindfulness on compassion, psychologists observed the responses of study participants to a woman on crutches who was wincing in pain. ${ }^{87}$ Some study participants had participated in a three-week mindfulness program using a mindfulness app. ${ }^{88}$ While only $14 \%$ of non-meditators offered their chair to the woman on crutches, $37 \%$ of the meditators acted to relieve her pain. ${ }^{89}$

Self-compassion helps lawyers manage their own painful or negative feelings and may help create an openness to taking risks. Under one definition, a person engages in self-compassion when she allows herself kindness and understanding in a painful situation, sees the painful experience "as part of the larger human experience," and has a "balanced awareness" that allows her not to disproportionately focus on the painful feelings. ${ }^{90}$ In her law review article about why law schools should teach mindfulness, Professor Shailini George discusses two studies that demonstrated a correlation between mindfulness meditation and an increase in self-compassion. ${ }^{91}$ One study revealed that college students managed negative personal and interpersonal events better with selfcompassion. ${ }^{92}$ A second study of health care professionals measured selfcompassion following an eight-week MBSR program. ${ }^{93}$ Researchers found a $22 \%$ increase in self-compassion. ${ }^{94}$

Cho and Gifford theorize that the increase in self-compassion that results from mindfulness practice is a positive development for creativity ${ }^{95}$ Engaging in self-compassion, abandoning negative self-perceptions, and letting go of fear of failure open the door to greater creativity. ${ }^{96}$

\section{Creativity}

All of the mindfulness benefits discussed so far can lead to a boost in creativity. Mindfulness training can increase creativity by increasing compassion and self-compassion and by providing a more relaxed state of mind that is not focused constantly on a fear of failure. Lawyers who are not fear-driven and constantly engaged in avoiding failure can better access creative thinking. ${ }^{97}$ Compassion can open up the lawyer to different perspectives to see core emotional concerns that were not apparent in a zero-sum game view of a client's problem.

87. David Desteno, The Kindness Cure, THE ATLANTIC (July 21, 2015), http://www.theatlantic .com/health/archive $/ 2015 / 07 /$ mindfulness-meditation-empathy-compassion $/ 398867 /$.

88. Id.

89. Id.

90. George, supra note 1 , at 235 .

91. Id.

92. Id.

93. Id.

94. Id.

95. See Cho \& GiFFORD, supra note 1, at 152 ("As we let go of the harsh narrative and holding ourselves to an impossible standard, we may be more inclined to take risks. When we aren't so fear-driven and engaged in avoiding failure, we can access creative thinking.").

96. Id.

97. Id. 
With mindfulness comes what some might describe as "open awareness."98 That "open awareness," bereft of judgment and "devil's advocate," can be a "mental platform for creative breakthroughs."99 Research on creativity also suggests that people come up with their greatest insights and biggest breakthroughs when they are in a more meditative and relaxed mode. ${ }^{100}$ "Eureka" moments occur often when people are in a more relaxed state of mind. ${ }^{101}$

\section{Implicit Bias}

Research has revealed possible links between mindfulness practice and the reduction of implicit bias. ${ }^{102}$ Rhonda Magee, a law school professor, has written extensively on the role of mindfulness in teaching about topics relating to social justice and racism in legal education. ${ }^{103}$ In her essay, How Mindfulness Can Defeat Racial Bias, Professor Magee discusses how mindfulness can help reduce bias:

[M]indfulness and compassion practices assist in raising awareness of our emotions and sensations in a given moment, regulating emotional responses and specifically reducing anxiety, increasing empathy and perspective-taking, and increasing overall gratitude and well-being. This all suggests that mindfulness and compassion practices may be important to creating the general conditions that support minimizing bias. ${ }^{104}$

Magee cites a study that suggested "even a 10-minute mindfulness practice reduced race and age bias on the Implicit Attitude Test, possibly by reducing participants' tendencies to automatically activate associations."105

98. See Goleman, supra note 4 , at 42 .

99. Id.

100. Emma Seppala, How Meditation Benefits CEOs, Harv. Bus. Rev. (Dec. 14, 2015), https:// hbr.org/2015/12/how-meditation-benefits-ceo.

101. Id.

102. Rhonda Magee, Life Experience and Cognitive Science Deepen the Case for Mindfulness in the Law, A.B.A. J. (Jan. 1, 2016), http://www.abajournal.com/magazine/article/experience_and_ cognitive_science_deepen_the_case_for_mindfulness_in_the_law/.

103. See, e.g., id.

104. Rhonda Magee, How Mindfulness Can Defeat Racial Bias, Greater Good: The Science OF A MisaningFul LIFE (May 14, 2015), http://greatergood.berkeley.edu/article/item/how_mindful ness_can_defeat_racial_bias. Also, Professor Rhonda Magee wrote in the ABA Journal, "Bolstered by research such as a study at Central Michigan University described in the April 2015 issue of Social Psychological and Personality Science, CLE programs are exploring the links between mindfulness and the reduction of implicit age and race bias. They are helping lawyers and leaders expand the set of tools and approaches available to seek conflict resolution effectively, productively and sustainably." Magee, Life Experience and Cognitive Science, supra note 102. See also Сно \& GIFFORD, supra note 1, at 126 ("[P]racticing compassion ... also serves to reduce your own bias in the case, from seeing the case only from your own perspective.").

105. Magee, How Mindfulness Can Defeat Racial Bias, supra note 104. 


\section{Foster Ethical Behavior}

Mindfulness tools can improve conflict resolution, foster ethical behavior, and avoid the negative emotions that sometimes get in the way of producing the best possible result for a client. ${ }^{106}$ Professor Rogers has advocated for the integration of mindfulness practice training with professional responsibility education. ${ }^{107}$ Emotionally charged circumstances can trigger violation of ethical rules and unprofessional conduct. ${ }^{108}$ Ethical violations can take place during moments of high stress. ${ }^{109}$ Thus, developing students' self-awareness and their ability to draw upon mindfulness practices that could bring about a reduction in overall levels of stress can help foster ethical behavior. ${ }^{110}$

Social media technologies have given rise to a growing number of ethics advisory opinions and disciplinary actions "stemming from the ability to express instantaneously an emotionally charged reaction." 111 Smartphones and the Internet have changed the way people, including lawyers, communicate and "have severely quickened the pace of our daily lives." 112 Lawyers are compelled to consider "the challenges of the practice through the lens of technology and its effect on professionalism and ethics," a task more effectively managed with mindfulness training. ${ }^{113}$

\section{Academic Achievement}

In theory, if mindful meditation increases attention, increases memory, and decreases stress, students should experience higher grades and standardized test scores with mindfulness practice. Studies exploring the connection between mindfulness practice and academic achievement are beginning to show such a positive correlation. ${ }^{114}$ In one study, 48 undergraduate students were randomly assigned to either a mindfulness class or a nutrition class. ${ }^{115}$ Over two weeks,

106. Martin, supra note 3, at 428.

107. See Jan L. Jacobowitz \& Scott Rogers, Mindful Ethics-A Pedagogical and Practical Approach to Teaching Legal Ethics, Developing Professional Identity, and Encouraging Civility, 4 St. Mary's J. Legal Mal. \& Ethics 198 (2014). See also Rogers, supra note 11, at 408-11; Scott L. Rogers \& Jan L. Jacobowitz, Mindfulness and Professional Responsibility: A Guide Book for Integrating Mindfulness into the Law School Curriculum (2012).

108. See Jacobowitz \& Rogers, supra note 108, at 227-28, 239.

109. Id.

110. Rogers, supra note 11, at 404.

111. Jacobowitz, The Benefits of Mindfulness for Litigators, supra note 51, at 29.

112. Id.

113. Id.

114. Research on mindfulness in education, specifically the connection between mindfulness and academic achievement, is ongoing. For example, Professor Amanda Moreno is conducting a 4year study that looks at a group of children in Chicago from their kindergarten through secondgrade years and assesses the impact of mindfulness practice on academic progress. Emily Deruy, Does Mindfulness Actually Work in Schools?, The ATLANTIC (May 20, 2016), http://www.theatlan tic.com/education/archive/2016/05/testing-mindfulness-in-the-early-years/483749/. See also Emily Campbell, Mindfulness in Education Research Highlights, Greater Good: The SCIENCE of A MEANINGFul LIFE (Sept. 16, 2014), http://greatergood.berkeley.edu/article/item/mindfulness_in_ed ucation_research_highlights; George, supra note 1, at 228.

115. George, supra note 1, at 228. 
students met in 45-minute class sessions four times per week. ${ }^{116}$ The students who attended the mindfulness class improved in academic achievement measured by a verbal-reasoning Graduate Record Examination score and a workingmemory capacity test. ${ }^{117}$ The students who attended the nutrition class did not experience any improvement in scores. ${ }^{118}$ In another study featuring undergraduate students, one group of students met for a one-hour meditation class two times a week that included "attentional focusing and relaxation exercises" and 10-minute meditations to begin and end each class. ${ }^{119} \mathrm{~A}$ second group of students met once a week as a study group without any meditation component to their study group meetings. ${ }^{120}$ For that semester, the group attending the meditation class had "significantly higher cumulative GPAs than the control group."121

Given all of the benefits of mindfulness training and how they complement the goals and benefits of legal technology training, a law school developing a legal technology program would miss out on maximizing the benefits of legal technology training without integrating mindfulness as a key component. The next section provides an overview of the rise of legal technology courses in law school curricula and the main drivers behind that rise.

\section{Legal Technology Training in Law School Curriculum}

As recently as 2013, legal tech "evangelists" decried the lack of legal technology learning opportunities in law school, discussing the topic as a crisis in law schools. ${ }^{122}$ A number of law school professors presented and wrote about the need to transform legal education on that front. ${ }^{123}$ In his 2013 article on developing an "e-curriculum," Professor Oliver Goodenough declared that a "technology-driven revolution [was] overturning how America practices law,"

116. Id.

117. Id. at 228-29 ("The students in both classes took a verbal-reasoning section from the Graduate Record Examination (GRE) and a working memory capacity test before and after the two weeks of classes. . . . The mindfulness students improved both their verbal GRE score by an average of sixteen percentile points, as well as their scores on the working memory capacity test.").

118. Id.

119. Id. at 229 .

120. Id.

121. Id.

122. Nicole Black, Things You Didn't Learn in Law School: The Benefits of Technology, MrCASE (Oct. 8, 2013), http:/www.mycase.com/blog/2013/10/things-didnt-learn-law-schoolbenefits-technology/. Black commented, "Unfortunately, most law schools completely ignore technology-related skills when designing their curriculums, whether it's legal software, Internetbased technology, e-discovery, or online marketing tools." Id. Professor Oliver Goodenough reported that law schools are "in crisis" in part because technology was "rapidly remaking the practice of law, and law schools [were] slow to respond." Michael Fitzgerald, 14 Reasons Law Schools Must Teach Tech, INFo. WK. (July 9, 2013, 7:09 PM), http://www.informationweek.com/ mobile/mobile-devices/14-reasons-law-schools-must-teach-tech/d/d-id/1110682.

123. See, e.g., Daniel Martin Katz, The MIT School of Law? A Perspective on Legal Education in the 21st Century, 2014 U. ILL. L. REv. 1431; Oliver Goodenough, Developing an E-Curriculum: Reflections on the Future of Legal Education and on the Importance of Digital Expertise, $88 \mathrm{CHI}_{\mathrm{HI}}$ KENT L. REV. 845 (2013). 
but he observed that such a revolution was "almost completely unnoticed by the people who teach aspiring lawyers." 124

Times are changing. Law schools have become increasingly focused on offering legal technology and innovation courses and programs to students. ${ }^{125}$ Legal tech is on the rise in legal education. ${ }^{126}$

This section will first provide an overview of the many forms that legal technology training can take in law school curriculum. It then turns to highlight law school legal technology programs and courses in the United States. Finally, this section sets forth the proffered goals and benefits of including legal technology in the law school curriculum. These stated goals and benefits overlap with, complement, and integrate well with the benefits of mindfulness training.

\section{A. Broad Spectrum}

Law school training in legal technology can and has taken many forms. History will likely mark this period as an experimental one in teaching legal technologies. The ABA Commission on the Future of Legal Services, in its 2016 report, noted that law schools are experimenting in "important ways." 127 The Commission reported that a "number of law schools now offer courses on ediscovery, outcome prediction, legal project management, process improvement, virtual lawyering, and document automation." 128 Specific courses and programs will be set out in the next section. Generally, though, they fall into several categories. A law school might have a well-funded "center" designated for legal technology and innovation training, with full-time faculty devoted to the center and to partnering with clients in the community and legal tech providers to give students an immersive experience. A law school might hire an adjunct professor who works for a legal process outsourcing company to teach a course in ediscovery or legal project management. A law school might offer students a certificate representing competence in legal technologies; students could earn the certificate by taking courses labeled by the school as related to legal technology. A law school might offer a "law and technology" course on technology trends in the legal profession that examines some aspect or effect of law and technology, such as ethical, global, economic, employment, or bias. Legal tech training can also be incorporated into long-standing parts of law school curriculum, such as legal research and writing courses. ${ }^{129}$ Also, some law schools are involved in consortiums, groups, or communities devoted to developing curriculum and

124. Goodenough, supra note 123 , at 847 .

125. Id.

126. Roy Strom, Law Schools' Tech-Training Conundrum: If We Teach Them, Will They Get Jobs?, Am. LAw. (July 20, 2016), http://www.law.com/sites/articles/2016/07/20/law-schools-techtraining-conundrum-if-we-teach-them-will-they-get-jobs/.

127. ABA, The Delivery of Legal Services in the United States: The Commission's Findings, in A Report on the Future of Legal Services in thi United States 19 (2016), http:// abafuturesreport.com/2016-fls-report-findings.pdf [hereinafter ABA, THE Commission's Findings].

128. Id. at 25 .

129. See, e.g., Katrina Lee, Susan Azyndar \& Ingrid Mattson, A New Era: Integrating Today's "Next Gen" Research Tools Ravel and Casetext in the Law School Classroom, 41 RutGers COMPUTER \& TeCH. L.J. 31 (2015). 
networks related to educating students in legal technology. ${ }^{130}$ In addition to legal tech curriculum additions, students might also be given opportunities to participate in various "challenges" or competitions. ${ }^{131}$

\section{B. Rise in Legal Tech Offerings}

Some law schools were ahead of the curve in developing legal technology curriculum options. Stanford, Brigham Young University, Chicago-Kent, and Vermont law schools all offered pioneering law and technology programs. ${ }^{132}$ As recently reported in The American Lawyer, a growing number of law schools have followed and are offering students opportunities to learn about legal innovation and technology. ${ }^{133}$ More than 20 law schools offer programs or courses that help law students explore the potential of software in delivering legal services. ${ }^{134}$

Law school curricula and programs relating to legal technology ${ }^{135}$ can take many different forms, from robust programs that involve extensive collaboration

130. See, e.g., All About LWOW, LAW WITHOUT WALLS, http://lawwithoutwalls.org/aboutlwow/ (last visited Nov. 18, 2016).

131. In November 2016, Thomson Reuters partnered with five law schools-Duke University School of Law; University of Missouri-Kansas City Law School; Suffolk University Law School; Brooklyn Law School; and Legal RnD at Michigan State University College of Law-for "The Product Design Challenge." Press Release, Thomson Reuters, Thomson Reuters Challenges Law School Students to Develop Next Generation of Legal Technology Products (Nov. 2, 2016), http:// thomsonreuters.com/en/press-releases/2016/november/thomson-reuters-challenges-law-school-stu dents-to-help-develop-next-generation-legal-technology-products.html. According to the Thomson Reuters press release, teams of law school students were invited to participate in an "intensive oneday event" "to develop proposals to expand the capabilities of Thomson Reuters Practice Point." Id. Practice Point is a legal solutions platform marketed by Thomson Reuters. See Practice Point, THOMSON REUTERs, http://legalsolutions.thomsonreuters.com/law-products/solutions/practice-point (last visited Nov. 16, 2016).

132. See Goodenough, supra note 123 , at 873-76.

133. Strom, supra note 126. Legal tech-related programs exist at several law schools including Brigham Young University Law School, Florida Coastal School of Law, Hofstra University Deane School of Law, University of Pittsburgh School of Law, and Vermont School of Law. Richard Granat \& Marc Lauritsen, Teaching the Technology of Practice: Top 10 Law Schools, A.B.A. L. PRAC. MAG. (July 2014), http://WwW.americanbar.org/publications/law_practice_magazine/2014/ july-august/teaching-the-technology-of-practice-the-10-top-schools.html. See also Richard Granat, 13 Top Law Schools Teaching Law Practice Technology, ELAwYering Blog (May 6, 2013), http:// www.elawyeringredux.com/2013/05/articles/competition/13-top-law-schools-teaching-law-practice -technology/ (reporting on initial list compiled by the eLawyering Task Force of the Law Practice Management Section of the ABA and listing Maurer School of Law at Indiana University, New York Law School, Northern Kentucky University Chase College of Law, and the University of Pacific, McGeorge School of Law, among others).

134. Law Schools and Technology, NEOTA LOGIC (Mar. 3, 2015), http://www.neotalogic.com/ law-schools-technology/.

135. Teaching legal technology is a fast-growing area. This article does not purport to provide an exhaustive list of existing legal technology programs and courses. Also, undoubtedly, upon the publication of this article, several new legal tech courses or programs will be announced. This article takes a broad approach to the meaning of legal technology curriculum, programs, and courses, and does not represent an exhaustive list of every instance of legal technology education in law schools. As the ABA itself has noted, law schools continue to experiment with different approaches to law practice technology teaching. The ABA eLawyering Task Force at one point set these criteria for inclusion of law schools focused on the teaching of legal technologies: 
with legal tech industry companies to individual courses that include some aspect of legal tech. The Illinois Institute of Technology's Chicago-Kent College of Law and Suffolk University Law School offer legal technology certificate programs. ${ }^{136}$ Also, Georgetown University Law Center runs an "Iron Tech Lawyer Competition" and a "Technology, Innovation and Law Practice" seminar. Georgetown's legal technology program has focused on "the development of legal expert systems using a variety of platforms."137 The Legal $\mathrm{RnD}$ Center, a pioneering program at Michigan State University Law School, is "dedicated to improving legal-service delivery and access across the legal industry" and trains students on legal services operations and litigation analytics concepts. 138 The Center emphasizes "organizational excellence,"139 and its website states, "We use lean thinking to implement standards, develop metrics, and collect and analyze data to test solutions. All of this is critical to improving legal-service delivery and laying a foundation for leveraging technology. . . . Organizational excellence can help address legal-industry problems such as work satisfaction, gender equality, and diversity." 140 Vanderbilt Law School offers a "Technology in Legal Practice" course. ${ }^{141}$ In that course, students spend class time working in groups assessing actual pro-bono client legal service issues and designing a legal application to solve an issue. ${ }^{142}$ Columbia Law School, the University of Pennsylvania Law School, and several other law schools offer legal-tech clinics or seminars. ${ }^{143}$ Cornell Law School now offers a Masters of Law in Law, Technology and Entrepreneurship. ${ }^{144}$ Through the program "Law Without Walls," University of Miami Law students collaborate in multidisciplinary teams to identify and propose solutions to legal problems using legal tech. ${ }^{145}$ The University of Colorado Law School initiated the Tech Lawyer

1. A full-time faculty member dedicated to teaching and coordinating a program in law practice technology. This subject matter should be the focus of serious research, including the development of innovations in law practice.

2. At least two credit courses in this subject matter such as law practice management, law practice technology, ediscovery and big data, outcome prediction, legal project management, virtual lawyering, expert systems development, document automation, and/or other coursework which deals with innovation in the delivery of legal services and law practice.

3. Non-credit courses taught by adjunct instructors don't qualify.

4. Law schools sponsoring incubator programs are interesting, but these programs involve lawyers who have already graduated, not law students.

Granat, supra note 133. See also Law Schools and Technology, supra note 134.

136. Strom, supra note 126.

137. Granat, supra note 133 .

138. Innovation to Increase Access to Legal Services, LEGALRND, http://legalrnd.org/ (last visited Oct. 31, 2016).

139. Id.

140. Id.

141. Course Information: Technology in Legal Practice, VAND. L. SCH., http://law.vanderbilt .edu/courses/340 (last visited Oct. 31, 2016).

142. Id.

143. Strom, supra note 126.

144. Master of Laws (LLM), CORNELL TECH, https://tech.cornell.edu/programs/mastersprograms/master-of-laws-llm (last visited Oct. 31, 2016). See also Strom, supra note 126.

145. All About LWOW, LAW WiTHOUT WALLS, http:/lawwithoutwalls.org/about-lwow/ (last visited Oct. 31, 2016). See also LegalHackers, 2016 Legal Hackers International Summit-Late- 
Accelerator program. ${ }^{146}$ As part of the program, students receive instruction "on how operational tools can be used to improve the delivery of legal services." 147 Law schools, including The Ohio State University Moritz College of Law and Chicago-Kent College of Law, offer a course in e-discovery. ${ }^{148}$ In spring 2015 , Chicago-Kent's e-discovery class enrollment increased by 33\% from 2014. ${ }^{149}$ Also, the University of Dayton Law School has announced it will offer a Technology Competencies Credential. ${ }^{150}$

Law school courses on legal informatics and quantitative analysis have been developed. The Stanford Law School course catalog offers this definition of legal informatics: "a computational perspective of law: where does legal information reside, how is it manipulated, and which algorithms and data structures are used in various legal functions?"15! The school offers a legal informatics course that "seeks to explore both the current trends and the future possibilities of this transformation, as we begin to train the future generation of technology savvy lawyers, and technologists who understand the intricacies and potential of what the law could be."152 Also, the Legal RnD Center offers "Quantitative Analysis for Lawyers." 153 MSU Law Professor Daniel Linna recommends that lawyers add value by learning quantitative basics such as "[t]he ability to read code, use statistical tools, and understand how artificial intelligence works."154

Legal design is also trending as part of legal technology education. The Legal Design Lab at Stanford Law School is one prominent trailblazing example.

Afternoon Presentations, YouTuBE (July 16, 2016), https://www.youtube.com/watch?v=erD3vNw eilk.

146. New Tech Lawyer Accelerator Program Garners Inaugural Access Group Grant, Colo. LAw (July 17, 2014), http://www.colorado.edu/law/2014/07/17/new-tech-lawyer-accelerator-pro gram-garners-inaugural-access-group-grant.

147. Id.

148. Course Information: E-Discovery Law, The Ohio STate UnIV. Moritz C.L., http:// moritzlaw.osu.edu/academics-old/courses1617.php?ID=3765 (last visited Oct. 31, 2016); Electronic Discovery, CHICAGO-KENT C.L., http://www.kentlaw.iit.edu/courses/jd-courses/jdelective-courses/electronic-discovery-prof-katz (last visited Oct. 31, 2016).

149. Adam Bottner, Should Legal Technology Be Studied in Law School?, LAw TECH. TODAY (Apr. 13, 2016), http://www.lawtechnologytoday.org/2016/04/know-youll-study-law-school-nextsemester/. Also, in the e-discovery arena, in 2016, Duke University School of Law acquired EDRM, "the leading standards organization for the e-discovery market." Zach Warren, Duke Law to Acquire EDRM to Advance E-Discovery Education, LEGALTECH NEws (Aug. 24, 2016), http:// www.legaltechnews.com/id=1202765807999/Duke-Law-to-Acquire-EDRM-to-Advance-EDiscov ery-Education?slreturn $=20161016135354$ (last visited Nov. 16, 2016). The acquisition could influence changes in law school curriculum. Id.

150. According to the University of Dayton Law School website, students pursuing the credential will be required to obtain a minimum number of core technology competencies by the time they graduate. Students can acquire the competencies through a combination of optional workshops and Dayton Law courses, where one or more of the competencies are taught. Technology Competencies Credential, U. DAYTON L. ScH., https://www.udayton.edu/law/academ ics/tech-competency.php (last visited Aug. 13, 2016).

151. Course Catalog: Legal Informatics, STANFORd L. ScH., https://law.stanford.edu/courses/ legal-informatics/ (last visited Oct. 31, 2016).

152. Id.

153. Daniel Linna, Why Law Students Should Take Quantitative Analysis: Big Data, Algorithms, Courtrooms, Code, and Robot Lawyers, LegalTech Lever (Oct. 22, 2016), http://www.legaltech lever.com/.

154. Id. 
The Legal Design Lab is an interdisciplinary team "working at the intersection of human-centered design, technology \& law to build a new generation of legal products and services" and to train law students and professionals. ${ }^{155}$

Also, some law schools work together to provide legal tech learning opportunities to their students. In 2016, Professor Margaret Hagan announced the formation of the Global Legal Technology Lab ("GLTL"). ${ }^{156}$ GLTL is described as "a network of law schools, legal technology companies, and other organizations interested in pushing forward new innovations in the legal system - particularly around access to justice." 157 A "driving idea" of GLTL is to "link projects across different schools and silos, stop duplication of efforts, and drive a stronger agenda of what the future of legal education and innovation should look like." 158

Thus, legal technology has become increasingly present in law school curricula across the country in recent years, and the momentum toward providing legal technology education continues to rise. Legal educators advocating for this development almost universally discuss the impact of legal technology on the practice of law and the speed with which that is taking place, along with the need for law schools and the legal profession to address the unmet need for all citizens to have access to justice.

\section{Goals and Benefits}

The many goals and benefits of including legal tech in law school curricula can be served even better with integrated mindfulness training. The inter-related goals and benefits of legal tech education commonly include concerns about access to justice, ethical obligations, efficiency, and job opportunities for students.

\section{Access to Justice}

The goal of increasing access to justice is frequently raised as a reason for teaching technology in law schools. Professor Goodenough discussed the "significant potential for automation to increase the reach of services like our law school legal clinics." 159 The American Bar Association's Commission on the Future of Legal Services' final report in 2016 contained a considerable focus on the link between access to justice and technology. For example, the report highlighted an access to justice collaboration involving Chicago-Kent College of Law where "A2J Author, a joint project between Chicago-Kent College of Law and the Center for Computer-Assisted Legal Instruction, has been used to reach nearly two million legal aid clients across the country to conduct automated

155. Welcome, LeGAl DeSIGN LAB, http://www.legaltechdesign.com/ (last visited Oct. 31, 2016).

156. Margaret Hagan, Law Schools as Innovation Hubs-The Global Legal Technology Lab, OPEN L. LAB (May 5, 2016), http://www.openlawlab.com/2016/05/05/law-schools-as-innovationhubs-the-global-legal-technology-lab/.

157. Id.

158. Id.

159. Goodenough, supra note 123 , at 872 . 
interviews and generate legal documents."160 Law schools, including Georgetown Law and Chicago-Kent, offer courses that require students to design legal access applications to help address the consumer need for affordable legal services. ${ }^{161}$

The Global Legal Technology Lab-initiated by the University of MissouriKansas City School of Law, Queen Mary University-London, Brooklyn Law School, and MIT Law-bills itself as a network of law schools that builds new technologies and launch projects to make the legal system more accessible, efficient, and empowering. ${ }^{162}$ The GLTL was launched with a particular emphasis on "access to justice." 163

\section{Ethics and $A B A$ Guidance}

In recent years, the $\mathrm{ABA}$ has moved in the direction of requiring law schools to teach law students relevant technologies. In August 2016, the ABA's Commission on the Future of Legal Services delivered its final report following a two-year study. ${ }^{164}$ The report made several recommendations related to technological changes in law practice. Those recommendations included:

- All members of the legal profession should keep abreast of relevant technologies;

- Courts should be accessible, user-centric, and welcoming to all litigants, while ensuring fairness, impartiality and due process;

- The ABA should establish a Center for Innovation ${ }^{165}$; and

- The legal profession should partner with other disciplines and the public for insights about innovating the delivery of legal services. ${ }^{166}$

160. ABA, THE Commission's Findings, supra note 127, at 27.

161. See Tanina Rostain, Roger Skalbeck \& Kevin G. Mulcahy, Thinking Like a Lawyer, Designing Like an Architect: Preparing Students for the 21st Century Practice, 88 CHI.-KENT L. Rev. 743, 744-46 (2013).

162. See generally Global Legal Technology Laboratory: Event Schedule, MIT L., https:// law.mit.edu/GLTL (last visited Oct. 31, 2016). See also Hagan, supra note 156.

163. Hagan, supra note 156.

164. ABA Futures Panel Recommends Sweeping Changes in Delivery of Legal Services, AM. BAR Ass'N (Aug. 6, 2016), http://www.americanbar.org/news/abanews/aba-news-archives/2016/ 08/aba_futures_panelre.html.

165. A law school dean, Andrew Perlman of Suffolk University Law School, serves as the inaugural chair of the Governing Counsel of the newly formed ABA Center for Innovation. $A B A$ Announces Council Members and Special Advisors for Its New Center for Innovation, AM. BAR Ass'N (Sept. 1, 2016), http://www.americanbar.org/news/abanews/aba-news-archives/2016/09/aba announces_counci.html ("The Center will advance the ABA's position as the lead architect of the legal profession's efforts to increase access to justice and improve the delivery of legal services through innovative programs and initiatives. It will serve as a resource for ABA members and operate a program of fellowships to work with other professionals, such as technologists, entrepreneurs and design professionals. The Center also will maintain an inventory of the ABA's innovation efforts as well as the efforts of the domestic and international legal services community.").

166. ABA Futures Panel Recommends Sweeping Changes in Delivery of Legal Services, supra note 164 . 
Also, the ABA Model Rules of Professional Conduct recognizes in a Comment that a lawyer should keep abreast of changes in the law and its practice, including the benefits and risks associated with relevant technology. ${ }^{167}$ The ABA has created a legal technology resource center to address how technology affects law practice. ${ }^{168}$

\section{Efficiency and Client Demands}

In recent years, lawyers have been subject to increased pressures from clients to improve efficiency and quality. ${ }^{169}$ For lawyers to meet these pressures, Professor Linna advocates that they need to be able to use "basic technology," including software that is used to create documents and software that is used to analyze information from clients. ${ }^{170}$ Becoming competent with that basic legal tech will lead to greater efficiency and minimize errors. ${ }^{171}$ For future litigators, it is important to understand how legal technologies "can help them attain the goal of Rule 1 of the Federal Rules of Civil Procedures, i.e., to secure the just, speedy, and inexpensive determination of every action and proceeding." 172 Given the pressures exerted from clients regarding efficiency and costs, the number of legal employers requiring basic technology proficiency will only increase. ${ }^{173}$

\section{Job Opportunities}

Legal technology education has the potential to expand the job opportunities available to today's law school graduates. ${ }^{174}$ Law school graduates who have experience in e-discovery and aspire to work in the private sector do not have to feel restricted to jobs at law firms or corporate legal departments. ${ }^{175}$ Graduates with e-discovery technology training will have the opportunity to join the $\$ 10$ billion industry of e-discovery. ${ }^{176}$ Moreover, even if a newly-minted law school graduate with some legal tech expertise elects to join a law firm as an associate, that graduate can more easily become the "go-to person in the firm" on ediscovery or other legal tech areas. ${ }^{177}$ Technology-savvy law school graduates

167. Model. Rules of Prof'L Conduct r. $1.1 \mathrm{cmt} .8$ (Am. BAr Ass'N 1983) ("Maintaining Competence: To maintain the requisite knowledge and skill, a lawyer should keep abreast of changes in the law and its practice, including the benefits and risks associated with relevant technology, engage in continuing study and education and comply with all continuing legal education requirements to which the lawyer is subject.").

168. See generally Legal Technology Resource Center, Ам. BAR Ass'N, http://www .americanbar.org/groups/departments_offices/legal_technology_resources.html (last visited Aug. 14, 2016).

169. Daniel W. Linna, Jr., 21st Century Legal Services? Lawyers and Law Students, You Can Learn These Skills, LegALTECH LeVER (Aug. 16, 2016), http://www.legaltechlever.com/2016/08/ 21 st-century-legal-services-lawyers-law-students-can-learn-skills/\#more-1820.

170. Id.

171. Id.

172. Bottner, supra note 149.

173. See Linna, supra note 169

174. Goodenough, supra note 123 , at 874-75.

175. Bottner, supra note 149.

176. Id.

177. Id 
could also take an enterprising route by developing "attractive software programs marketed to others" in a competitive legal market. ${ }^{178}$

Michigan State University Law School and Suffolk University Law School have shared some promising data on employment. Professor Linna reported that "our LegalRnD students have found no shortage of legal innovation and technology opportunities." 179 LegalRnD students who had completed a substantial portion of the LegalRnD curriculum worked in internships at legal employers including Elevate Services and Eris Industries. ${ }^{180}$ As of September 2016, LegalRnD graduates had full-time positions at legal employers including Elevate Services, Seyfarth Shaw, and LexPredict. ${ }^{181}$ Similarly, Suffolk University Law School shared employment results for students who completed its Law Practice Technology Concentration. There, in 2015, "five students complete[d] the [Law Practice Technology] Concentration, and about 50 other students took a portion of the core classes [for the concentration], which were all oversubscribed." 182 All five students found full-time employment in nontraditional legal jobs, with two of the students now working at Am Law 200 firm Davis Wright Tremaine in the research and development group, and another employed at a document automation company. ${ }^{183}$

\section{Law Schools Should Deliberately Link Mindfulness and Legal Tech in the Curriculum}

The trends of contemporary mindfulness and legal technology curriculum arose nearly simultaneously. Precursors and pioneers started to appear in the 1990s. Today, more than ever before, law schools are paying attention to the broad and multiple benefits of teaching mindfulness and legal technology to students. Although scholars have linked the existence of social media and technology with the need for finding a mindfulness answer to the problems of distractions and shorter attention spans, legal technology and mindfulness education have largely developed separately.

Outside of legal education, technology and mindfulness have already been linked, and law schools should take note and follow suit. A strong connection has

178. Professor Deborah Merritt discusses the potential advantage of "technology-savvy" law school graduates in a competitive legal market. She specifically stated, "Technology-savvy JDs will profit by developing attractive software programs marketed to others." Deborah J. Merritt, Why Has Law Practice Changed?, Law ScHOOL CAFE (Dec. 8, 2013), http://www.lawschoolcafe.org/ thread/why-has-law-practice-changed/.

179. Professor Daniel Linna recently highlighted several employment examples that "illustrate the opportunities available to law students trained in legal innovation and technology." Daniel W. Linna Jr., No Conundrum, \#LegalTech and Innovation Training Helping Law Grads Get Jobs, LeGALTECH Lever (Sept. 20, 2016), http://www.legaltechlever.com/2016/09/no-conundrum-legal tech-innovation-training-helping-law-grads-get-jobs/ (last visited Sept. 20, 2016).

180. Id.

181. Id.

182. Strom, supra note 126.

183. Id. 
developed between mindfulness and tech start-up culture in Silicon Valley. ${ }^{184}$ For example, Google pioneered the "Search Inside Yourself" training. ${ }^{185}$ The company holds "'mindful lunches,' conducted in complete silence except for the ringing of prayer bells." 186 Google also built a labyrinth for walking meditations. ${ }^{187}$ In 2014 , the pioneering tech company Intel initiated a program that made a 9-week mindfulness course available to its more than 100,000 employees around the world. ${ }^{188}$ In the 2016 book Mindful Tech: How to Bring Balance to Our Digital Lives, Professor David Levy explores "how to live a rich and meaningful life while participating in both the Fast World and the Slow World - in the fast-paced, crazy-busy, information-intensive world ... and in the slower-paced, calmer world that we sometimes touch in moments of quiet contemplation." 189

Law students would benefit from a recognition by legal educators that, with technology in law practice, come distinct challenges-including distraction and the downsides of multi-tasking. Professor Rogers offers a compelling case in support of integrating mindfulness into the professional responsibility curriculum, as many modern ethics issues arise from use of social media under emotionally charged circumstances. ${ }^{190}$ In a similar vein, introducing legal tech at the same time as mindfulness training would affirm for students the connection between mindfulness practice and responsible, productive use of legal technologies.

If law students are only trained on the "fast" aspects of law practice-that is, rapidly evolving legal technologies - and not on the impactful "slow" aspects of law practice - that is, the contemplative part of law practice-law schools miss out on a big teaching moment. Technology represents a great advance in law practice, but even greater advancement can be achieved if it is used mindfully and by lawyers who have been trained to "slow down" in their approach to technology use and design. The following section discusses at least a few ways in which the integration of mindfulness training in legal tech curriculum could enhance law students' learning.

184. See generally Noah Schachtman, In Silicon Valley Meditation Is No Fad. It Could Make Your Career, WIRED (June 18, 2013), http://www.wired.com/2013/06/meditation-mindfulnesssilicon-valley/.

185. Id.

186. $I d$.

187. Id.

188. Kristine Wong, There's No Price Tag on a Clear Mind: Intel to Launch Mindfulness Program, The GuARDian (Apr. 8, 2014), https://www.theguardian.com/sustainable-business/priceintel-mindfulness-program-employee.

189. David M. Levy, Mindful. Tech: How to Bring Balance to Our Digital lives, at ix (2016).

190. Rogers, supra note 11, at 402-04. 


\section{A. Mindfulness and Main Areas of Legal Technology Focus in Law Schools}

\section{Accessing Justice and Minimizing Bias}

Access to justice is frequently invoked as a reason for law students to learn legal tech while in law school. ${ }^{191}$ So far, much of legal tech education in law schools has focused on user-centered design and the application of tech tools, design principles, and creativity to increase access to justice. ${ }^{192}$ Some of legal tech education has also extended to addressing legal profession issues such as gender equality and diversity. ${ }^{193}$

Assuming access to justice is a major goal of legal tech education, mindfulness practice should play an indispensable role in legal tech education. As mentioned earlier, research shows that mindfulness training can help create "the general conditions that support minimizing bias." 194 If law students are to be engaged in designing legal tech applications or tools that help ordinary citizens obtain affordable and necessary legal services, they should approach their projects under circumstances optimal for eliminating or minimizing bias. Such circumstances can help students be more user-centered and more effective in designing legal access applications. Law students charged with designing or developing applications that help increase access to justice could do so successfully by first or simultaneously engaging in mindfulness exercises, before collaborating and brainstorming about possible solutions.

Also, a focus of legal tech and innovation curriculum has been user-centered design. Students who gain an increased ability to empathize through mindfulness training will be in a better position to address the needs of the user in any usercentered project.

\section{Creativity}

Using legal technologies to come up with solutions and new designs for delivery of legal services requires creativity and innovative thinking. Mindfulness training can boost the ability of students to succeed on their task because it can help create the circumstances for enhanced creativity. Tech companies have seen some promising results in this area. At the technology company Intel, 1500 employees participated in nineteen mindfulness sessions.

[Those employees experienced, on average] a two-point decrease (on a 10-point scale) in experiencing stress and feeling overwhelmed, a three-point increase in overall happiness and wellbeing, and a two-point increase in having new ideas and insights, mental clarity, creativity, the ability to focus, the quality of relationships at

191. See supra Part III.C.1.

192. See supra Part III.B.

193. See, e.g., Innovation to Increase Access to Legal Services, supra note 138 ("Organizational excellence can help address legal-industry problems such as work satisfaction, gender equality, and diversity.").

194. Magee, How Mindfulness Can Defeat Racial Bias, supra note 104. 
work and the level of engagement in meetings, projects and collaboration efforts. ${ }^{195}$

The results of Intel's survey align with the idea that mindfulness training can help minimize negativity and fear-driven lawyer behavior and, in that way, help law students and lawyers access creative thinking. ${ }^{196}$ Reduction of stress and elevated happiness can thus enable a law student to learn applied legal tech to be more creative. Another way mindfulness training can lead to increased creativity is by helping develop compassion. Compassion can help law students understand their (fictional or real) clients' problems more fully and open the door to increased perspectives and creative solutions. ${ }^{197}$

\section{Efficiency and Workflow}

In teaching about efficiency, workflow, and collaboration, some law school educators are already giving students tools to minimize multi-tasking and thereby increase efficiency. So much of legal technology in law practice helps streamline law practice to make it efficient and leaner. Mindfulness training can minimize distractions and further enhance efficient use of legal technology. I propose for mindfulness training to be used hand-in-hand with other efficiency and workflow techniques already used in legal technology programs.

For example, at one law school, law students are taught through use of the "Kanban method" that task-switching is inefficient. ${ }^{198}$ Kanban is a project management tool that Professor Linna teaches to his students. ${ }^{199}$ Anyone can set up a Kanban board. ${ }^{200}$ The board must contain several columns that represent work stages. ${ }^{201}$ Sticky notes or cards are used to represented tasks that need to be completed. ${ }^{202}$ Lawyers create three columns that represent these three work stages: "To Do," "Doing," and "Done."203 If a lawyer is doing new work on a new matter for a client, the lawyer creates cards or sticky notes with tasks written on them, and those go in the "To Do" column. ${ }^{204}$ When starting on a task, the lawyer moves a card from the "To Do" to the "Doing" column. ${ }^{205}$ Kanban helps with efficiency and helps constrain the amount of work in progress. ${ }^{206}$ Through Kanban, team members can more easily spot bottlenecks in workflow and focus on a given task rather than many at once. ${ }^{207}$

195. Wong, supra note 188.

196. Сно \& GIFFord, supra note 1 , at 152.

197. Id. at 117 .

198. What Is Kanban?, DiGıTé, http://www.digite.com/kanban-guide/what-is-kanban/ (last visited Nov. 18, 2016).

199. Id.

200. Ilina Rejeva, Kanban for Law Firms: A New System that Speeds Up Work Flow for Clients, LEGALTREK (Mar. 8, 2016), https://legaltrek.com/blog/2016/03/kanban-for-law-firms/.

201. Id.

202. Id.

203. Id.

204. Id.

205. Id.

206. Id.

207. Id. 
Mindfulness training combined with a tool like Kanban in legal technology and innovation courses could make efficiency lessons more powerful. Students would strengthen their ability to minimize distractions and stay focused on the task at hand.

\section{B. Ideas for Integrating Mindfulness into the Legal Tech Curriculum}

Integrating mindfulness into the legal tech curriculum could take many forms, ranging from those requiring very few resources to others requiring more resource investment. This section provides the following ideas about how integration of mindfulness into legal technology education could be implemented.

\section{A Mindfulness Training Course as a Prerequisite for All Legal Technology and Innovation Courses}

Law schools could require mindfulness training as a prerequisite for all legal technology and innovation courses. Just by requiring such training, law schools would signal to law students that mindfulness training and its benefits are foundational to their success in learning and innovating with legal technologies.

\section{Mindfulness as a Module in a Legal Technology Course}

Law school professors engaging in legal tech training could routinely include mindfulness training as a module in their courses. ${ }^{208}$ For example, a course on legal practice automation could include one or two sessions of mindfulness training for students with a meditation coach.

\section{A Mindfulness and Legal Technology Course}

Law schools could invest in resources to develop a mindfulness and legal technology course. An engineering school course at Northwestern University, "Emotional Intelligence 101," could provide an instructive model. ${ }^{209}$ The course covers topics related to emotional intelligence, like stress management, selfperception, and interpersonal relationships. ${ }^{210}$ Students engage in mindfulness meditation at the beginning of each class. ${ }^{211}$ They are "instructed to non-

208. Mindfulness training has been successfully incorporated into a law school skills course. For example, David Zlotnick, a professor at Rogers Williams University School of Law, has incorporated mindfulness training into his trial advocacy training for several years. Mindfulness in Legal Education, BERKLEY L., https://www.law.berkeley.edu/students/mindfulness-at-berkeleylaw/resources/mindfulness-in-legal-education/ (last visited Oct. 31, 2016).

209. Amanda Morris, Keeping Emotions in Mind, Nw. McCormick SCH. EngineEring Mag. (Fall 2015), http://www.mccormick.northwestern.edu/magazine/fall-2015/keeping-emotions-inmind.html.

210. Id.

211. Id. 
judgmentally recognize when their attention has wandered and to steer it back to their intended focus." 212

A law school course could integrate mindfulness training by simply discussing how legal technology use and innovation could be greatly advanced by mindfulness. For example, students could engage on the topic of how mindfulness practice might impact bias in the development of legal software algorithms and artificial intelligence. Students could also learn about the intersection of emotional intelligence and user-centered design.

\section{A Center on Mindfulness and Legal Technology}

Much has already been written and done concerning mindfulness and technology, beginning with the Google "Search Inside Yourself" program. Legal technology is a form of technology that carries with it unique professional identities, ethical responsibilities, and the power to transform communities and lives. A center devoted to research and teaching of how the benefits of mindfulness can enhance and transform legal technology use, development, and innovation could be a fruitful development for law students and the legal profession.

\section{Join Forces with Other University Departments}

Students' exposure and training in mindfulness and legal technology need not be limited to law schools. Interdisciplinary collaboration across a university campus on mindfulness has great promise. Law schools that are part of a university could join forces with other departments and offer interdisciplinary courses open to students pursuing degrees as varied as engineering, philosophy, psychology, education, business, pre-med, and design.

Some professors in the STEM fields have discussed and explored an interdisciplinary engineering or science curriculum that would include mindfulness as a central feature. For example, Virginia Tech University engineering professors have put forth a vision for an interdisciplinary mindful engineering curriculum. ${ }^{213}$ Professor Riskin has presented on mindfulness to students at the Northwestern University McKormick School of Engineering. ${ }^{214}$ Such a curriculum could include a course that explores the synergies of legal technologies used in the legal profession and the many benefits of mindfulness.

\section{Id.}

213. See Roop Mahajan, Engineering 2029 and Mindfulness: Contemplating the Engineering Curriculum, VA. Tech Inst. for CRitical Tech. \& ApPlied Sci. (Apr. 2013), http://www.cpe.vt .edu/cpts/presentations/mahajan.pdf. See also Gargi Singh, Contemplative Practices Part 3 (Engineering and Science Higher Ed), PHD DiARIES (Apr. 22, 2013, 2:30 PM), http:// whatzcookinlab.blogspot.com/2013/04/contemplative-practices-part-3.html.

214. A video of his presentation is posted on the McKormick School of Engineering website. Leonard Riskin, Mindfulness in the Engineering Profession, Nw. MCCoRMick SCH. EngINEERING (Sep. 14, 2016), http://www.mccormick.northwestern.edu/personal-development/self-improve ment-resources.html. 


\section{Support of Student Affinity Groups}

Law schools can support the creation of student affinity groups focused on mindfulness practice. ${ }^{215}$ Interested faculty members could serve as faculty advisors or assist with group programming.

\section{Mindfulness Resources on a Law School's Legal Technology Program Website}

At very little cost, law schools offering legal technology courses or programs could simply link to mindfulness resources on the portion of their website devoted to those courses or programs. The Northwestern McCormick School of Engineering, for example, has a link to "Self-Improvement Resources." 216 That link leads to the video of the "Mindfulness in Engineering" video of the presentation by Professor Riskin mentioned earlier. ${ }^{217}$ Similarly, law school websites devoted to legal technology programs could include links to mindfulness resources for lawyers. ${ }^{218}$ Resources linked to could include a list of books on mindfulness, a list of mindfulness meditation apps like Headspace and Calm, and free guided mindfulness meditations provided by the UCLA Mindful Awareness Research Center, The Ohio State University Wexner Medical Center, and other educational institutions. ${ }^{219}$

\section{CONCLuSion}

Legal education continues to make strides in offering legal technologyrelated coursework. Based on the latest ABA Commission on the Future of Legal Services report, legal education is likely on the cusp of an era in which the number of legal tech courses increases at a more rapid rate than ever before. As others have thoughtfully argued, educating law students about legal technologies is critical to the future of the legal profession and to any hope that true access to justice is achieved.

Law schools should continue to experiment with integrating legal innovation and technology into its curriculum hand-in-hand with trying to harness the potentially enormous benefits of mindfulness practice for their

215. Professor Austin suggested that "Students and lawyers can form affinity groups for exercise or contemplative practices, and law schools can facilitate these relationships." Austin, supra note 12 , at 854 .

216. Id.

217. Id.

218. See, e.g., Mindfulness at Berkeley Law: For Law Students, BERKLEY L., https://www.law .berkeley.edu/students/mindfulness-at-berkeley-law/resources/for-law-students/ (last visited Oct. 31, 2016).

219. See, e.g., Get Some Headspace, HeadSPaCe, https://www.headspace.com/ (last visited Nov. 18, 2016) ("meditation made simple"); Welcome to Calm, CALM, https://www.calm.com/ (last visited Nov. 18, 2016) ("[A] simple mindfulness meditation app that brings clarity and peace of mind into your life."); Mindfulness Practices, The Ohio St. Univ. WeXner Med. Ctr., https:// wexnermedical.osu.edu/integrative-complementary-medicine/mindfulness-practices (last visited Nov. 18, 2016); Free Guided Meditations, UClA Mindful Awareness Research Ctr., http:// marc.ucla.edu/body.cfm?id=22 (last visited Nov. 18, 2016). 
students. Millions of consumers with unmet legal needs, and the legal profession itself, could benefit greatly from law school graduates who have been trained to take a mindful approach to using legal technologies and designing legal applications. The link between tech culture and mindfulness is not a novel one, as exemplified by the mindfulness programs offered by Google, Intel, and other tech companies. Legal educators should take heed and bring mindfulness into the legal technology fold. With the technologies available and being developed today, law schools have an unprecedented opportunity to maximize the benefits of their law students' legal technology education. Deliberately bringing mindfulness into the legal technology curriculum will help ensure full realization of that opportunity. 


$$
\text { . }
$$

